\title{
John Donne’s “Holy Sonnets”: Spiritual Experience in Poetry
}

\author{
Julieta C. Mallari \\ University of the Philippines Extension Program in Pampanga, Pampanga, Philippines
}

\begin{abstract}
This paper attempts to interpret Donne’s “Holy Sonnets” as spiritual experiences. Donne’s works are better understood through the optic of Biblical knowledge, the backdrop of God's revelation of Himself. A poet whose heart is kindled by the Spirit of his Maker and whose mind is illumined by His Word recognizes a much deeper sense of transcendent reality. As Donne uses the most potent but intimate of words to express his interaction with God, his sonnets ground the sacred. In their fluctuating moods, the sonnets reverberate as radically varied experiences of God. Grand theological truths are translated into personal and passionate encounter with God.

Keywords: John Donne, Holy Sonnets, spiritual experience, poetry
\end{abstract}

\section{Introduction}

The faith of a writer may be related to major aesthetic concerns, particularly the nature of the creative process and the extent of art as religious expression (Dyrness, pp. 206-207). A Christian writer has his inherent and deeply entrenched religious commitment that usually governs his works. Gordon Allport describes "the religious drive as a person's master sentiment, giving comprehensive ultimate shape to all his experiencing, whereas the poetic drive would be a further concrete specification of the same dynamism” (cited by Ruland, p. 4). In the same vein, when the gift of creativity is added to the gift of faith, "The work takes on a resonance that no other inspiration is likely to give” (Arland, quoted by Dyrness, p. 215).

Literary works that express the sacred can be distinctly recognized as the gift of faith becomes a generative force, channeled into the unitary act of religious-poetic experience. The unfolding of the metaphysical layer of the texts — which marks an aspect of Christian aesthetics—reveals the sphere of spiritual passion being intensified by the poet's triumph in evoking emotions.

Significantly, the beauty derived from works of art is attributed to the source of both the gift of art as well as the gift of faith. Ultimately, God can be praised for the beauty of each artistic testimony (Rookmaaker, p. 248); even more so if the testimony is to dovetail into a sacred act in which God Himself is experienced.

This grounding of the sacred in poetry brings the discussion to the blending of the two gifts-an interpenetration that lends expressiveness to a Christian poet and provides his spiritual experiences an artistic form.

\section{The Gift of Faith and Artistic Testimony}

When God's Word is planted in the fertile soil of poetic imagination, the seed germinates, blossoms, and yields creations reflecting eternal Beauty and Wisdom. Excellences in sentiment, subtleties in thought, and

Julieta C. Mallari, Ph.D., Professor, University of the Philippines Extension Program in Pampanga.

Correspondence concerning this article should be addressed to the University of the Philippines Extension Program in Pampanga, Clark Field Special Economic Zone, Clark Field, Angeles City, Pampanga, 2009, Philippines. 
originalities in expressions conspire to sharpen vision of the divine and substantiate experience of the supernatural. Religious-poetic experience is therefore meaningfully actualized and issued in literary constructs.

A poet whose heart is kindled by the Spirit of his Maker and whose mind is illumined by His Word recognizes a much deeper sense of transcendent reality: the divine activity invading and pervading the human realm. Seeing with the eye of faith, a Christian poet comprehends God's absolute creativity from which is derived his own creaturely art. He is fully aware of his artistic duty and joy as being reflective only of the "originality" which is the "prerogative of God alone," (p. 6) as C. S. Lewis puts it. Christian poethood, therefore, nurtures a creative spark ready to burst, at the touch of the original Creator, into literary flames. The poet does not steal fire from heaven as an act of rebellion, but he is in harmony with his God and shares the magnificence of His creative act.

However, the harmony is not absolute since the poet, who is part of humanity marred by moral failure, experiences a recurrent discord as he waits for deliverance from the "bondage of corruption" (Rom. 7:24). This infirmity is a reality that is inevitably expressed in his poetry to exhibit authenticity and fidelity to the human condition. The sin indwelling in his flesh is an existential fact, not simply a doctrinal formulation. Ugliness persistently taints his conception of human beauty, and darkness incessantly haunts his soul craving for the divine light. Like the Apostle Paul, he is aware of the "law in (his) members, warring against the law in (his) mind” (Rom. 7:23). Such tension is also vigorously reflected in the words of a Dostoevskian character:

Beauty! It makes me mad to think that a man of great heart and intelligence should begin with the ideal of Madonna and end with the ideal of Sodom. What is more terrible is that a man with the ideal of Sodom already in his soul does not renounce the ideal of Madonna, and it sets his heart ablaze.... (pp. 123-124)

The dark side of beauty lurks in the very soul of a Christian poet, but there is also the persistent divine force which "sets his heart ablaze": the contemplation of beauty based on God's revelation in Christ. Since a Christian poet creates always with reference to a living God, he recognizes the possibility of resolving such "war" and of healing man's brokenness through genuine spiritual regeneration. God's grace and power to transform man provides hope and "freedom from the law of sin and death" (Rom. 8:2). For the poet, this conversion is meaningful since the restoration of the image of Christ in him enhances his artistic sensitivity as he adds "to the intense observation of the artist the insights of faith" (Dyrness, p. 208). His vision now transcends the natural, thus his perception becomes truly holistic as it roams freely over life's multiplicity. The myriad human affairs and emotions, the mysterious depths of reality, the unlimited heights of experiences-these entire he avows and views in the divine light.

Manifesting the imago Dei, the Christian poet creates "after his own image” (Dyrness, p. 207). Moreover, C. S. Lewis says, "every mode of human excellence is implicit in His human character: poethood, of course, included” (p. 3). Paradoxically enough, the Christian poet's self-originating force in his creative act is derivative, a mirror reflection of the original Poet. Since the former has such creative impulse that is founded on his faith, his poetry is given life and meaning by the incarnate Son of God. That "beauty is Christ"-a Dostoevskian dictum —is affirmed in the poet's contemplative creative act. The fertilizing power of his mind joins in manifold witness those who proclaim the "glory of the Lord." As an inverse of Luther's idea, knowledge of Biblical theology actually makes literature endure. It is in this knowledge as well that appreciating literary works and sharing the poet's experience as the basis of Christian aesthetics could center. 
This paper attempts to interpret selected John Donne’s "Holy Sonnets” as spiritual experiences. Through the optic of the aforementioned Biblical knowledge, the "Holy Sonnets" may be read to appreciate and understand even more their inner splendor. Donne is an outstanding literary man whose intellectual vigor has woven the finest texture of poetry. Contrary to Johnson's statement that "Contemplative piety, or the intercourse between God and the human soul, cannot be poetical” (p. 291), Donne translates his religious thoughts and feelings into vibrant art. Indeed, he is a metaphysical poet using a device: "the elaboration (contrasted with the condensation) of a figure of speech to the furthest stage to which ingenuity can carry it," to quote T. S. Eliot (p. 60). His spiritual motivation finds a medium so fit, in fact, because in poetry his inner being achieves integration; in metaphysical poetry the divine truths which demand expression and move a person to prayer blossom like flowers to become sources of boundless satisfaction, be it spiritual or aesthetic or both.

It is assumed in the discussion that the persona speaking in the poems is the poet himself; his sonnets are similar to the Biblical Psalms comprising "a sampling of spiritual journals, much like personal letters to God" (Yancey, p. 112). Similar to David whose life was "a torrent of spiritual desire and his psalms ring[ing] with the cry of the seeker...” (Tozer, p. 16), Donne seeks God and communicates with Him through his poems, which in turn become God's avenues for His self-revelation. Donne seeks God, not without "a right thought of Him...a work of enlightenment done within him....” (Tozer, p. 11) as "God is always previous" (von Hugel quoted by Tozer, p. 12). In other words, as he expresses his thoughts to God, an inward revelation has already taken place: God-consciousness seizes upon him, giving him piercing spiritual perception.

"A thought to Donne was an experience," according to T. S. Eliot (p. 64), and in the "Holy Sonnets" Donne's thoughts explore his spirit with divine illumination that sustains his poetic-religious experience.

\section{The "Holy Sonnets"}

The "Holy Sonnets" take the form of meditation, as most critics note, as well as the Sidnean sonnet arrangement in limiting the rhymes of octave to two. It is the clever choice of Donne to employ this artistic structure that makes his works all the more authentic: "Holy Sonnets" lives up to the concepts being evoked, and in that title, the provinces of the sacred and the beautiful are yoked together, not violently like his conceits, but tenderly.

As Christian meditation, each sonnet is "thinking over in God's presence what God tells [Donne] about Himself and [Donne]. It is an exercise of realization and application, leading on to direct address to God in the speech and song of prayer and praise” (Packer, p. 7). In Donne’s case, he engages in a realistic dialogue with God by employing his analytic self-examinations and imploring Him to synchronize what he believes about Him with his spiritual experience.

When Donne says, "All divinity is love or wonder," (A Valediction: of the booke, 1.30) he articulates the very essence of his joy in the God he pursues. Significantly enough, he equally loses himself in humble penitence, throwing himself before his Savior as he desperately expresses his sense of personal unworthiness. His sonnets, "holy" as they are, contain the outpourings of his heart to God. They are direct, unadorned but passionate. The soul in deep communion with his Maker is presented: there is the undisguised, honest revelation of a self totally sensitive to the smell of death, both spiritual and physical, as well as to the soothing effects of divine grace. In these spiritual tensions lies the beauty of Donne's poems. From his inner being flows a vigorous stream of thoughts sent spontaneously to his Creator. And these ejaculations are translated into decisive poetic form, like gems emitting their own individual glitter. 
Having a solid Biblical foundation, Donne is able to distil with much temperance his personal pietism. His religious framework, shaped by unique blending of his Ignatian and Anglican backgrounds, transports him to a bottomless metaphysical pursuit. It is essentially his sound, Scriptural theology that regulates what could have been his radical super-naturalist projection. He is a balanced poet-theologian unraveling various facets of his faith.

Leon Bloy once said, “Sainthood is a 'grant' alien to man—alien and yet precious” (quoted by Dyrness, p. 39). This dictum applies to Donne's reflection upon his own nature: that being human, he is a sheer object of God's grace though he is not fit for it. Because of his depravity, the poet "comes short of the glory of God" (Rom. 3:23). In his "Holy Sonnets" the longing for deliverance from sin and death is a dominant note. The pathos appropriate to spiritual struggle is raised to huge proportions as demonstrated in Sonnet I:

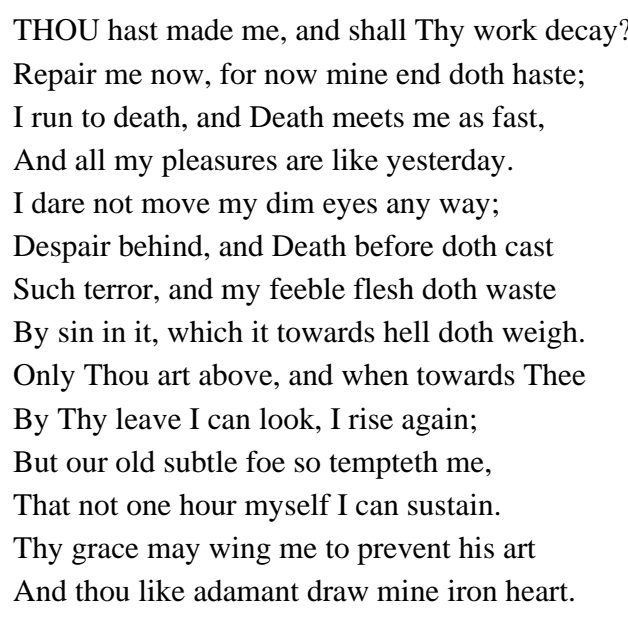

Donne establishes the specific relation between him and God, the creature and the Creator, the sinner and the Savior. "Thou hast made me” is reminiscent of St. Augustine’s "Thou hast formed us for Thyself...” Given this solemn fact, Donne asks his Maker the taunting rhetorical question "shall Thy work decay?” and allows their relationship to come into play in his personal struggle. He grapples with himself when he thinks of his "feeble flesh": his agony projects the raw power of such unflinching admission and rational outpouring in recognizing his predicament. Terror grips him as he sounds the consequence of sin, "towards hell," echoing Romans 6:23: "the wages of sin is death.” In distress, Donne turns to God and brings to Him what he sees in himself as hopeless disarray. "Repair me now" insinuates itself into the heart of the matter, i.e. his consciousness of his brokenness that only God can mend. For the poet to address God directly, an awakening of his spiritual senses is necessary to grasp the immensity of God's moral authority and to declare his humble submission. In his sonnet, he appeals to God and, at the same time, challenges Him who alone can make him whole, to rescue him from his desperate state.

Donne's sonnet unfolds a self-evident fact that he is acquainted with God to the extent that he uses his knowledge of Him in articulating the essential dynamics of his spiritual condition. This knowledge precedes God's revelation and His silent eloquence in their dialogue.

Donne's meditation on his personal sin and wantonness is more pronounced in Sonnet III:

$\mathrm{O}$ ! might those sighs and tears return again Into my breast and eyes, which I have spent, 
That I might in this holy discontent

Mourn with some fruit, as I have mourn'd in vain.

In mine idolatry what showers of rain

Mine eyes did waste ? what griefs my heart did rent?

That sufferance was my sin, I now repent;

'Cause I did suffer, I must suffer pain.

Th' hydroptic drunkard, and night-scouting thief,

The itchy lecher, and self-tickling proud

Have the remembrance of past joys, for relief

Of coming ills. To poor me is allow'd

No ease; for long, yet vehement grief hath been

Th' effect and cause, the punishment and sin.

What is immediately perceived in the preceding sonnet is the searching question that points to a distressed state of mind of someone trapped in the mire of sin: an echo of David's rueful Psalm 51, written after he committed adultery and murder (2 Samuel 11 and 12). Through the sonnet, his inward looking ushers him into spiritual disturbance: Donne cries out from anguish and, as it were, beats his breast and ruminates on his sinfulness. Through this act of contrition he involves God and His Son who came to seek and save the lost like him. The discordant note of his lament over his entanglement with sin is actually his response to the Savior's mission: Christ has "not come to call the righteous but sinners to repentance" (Luke, 5:32).

And then again in Sonnet 1V,

Oh my black soul, now thou art summoned

By sickness, Death's herald, and champion;

$\ldots$

Oh make thy self with holy mourning black

And red with blushing, as thou art with sin;

(1V. 1-2, 11-12)

As has been mentioned, Donne's Scriptural knowledge, which he underlines with immense poetic dexterity, provides the built-in theological dimension of his works. The implications of several persisting themes of Christianity are rendered meaningfully as they become a personal revelation. Sin, the wages of which is death, for instance, is a Biblical doctrine dramatically illustrated. The previously quoted Sonnet IV lines exemplify the appropriation of the Christian doctrines to the poet's own life. It should be pointed out that death, the consequence of the fall of man, has three Biblical meanings: physical (1 Cor. 15:21,22; Hebrew, 9:27; Romans, 5:12), spiritual (Ephesians, 2:1, 4:18; 1 Timothy, 5:6; 1 John, 5:12) and eternal (2 Thessalonians, 1:9; 1 Corinthians 6:9,10; Matthew, 25:30, 41,46). Donne evidently realizes to the fullest measure the severity of this judgment on man. The travails of his soul, therefore, as projected in the sonnets, testify to the existential reality of the horrors of death.

First, he experiences spiritual death, i.e., the gulf created by sin between God and man. Estranged from his Creator, he suffers from spiritual deprivation and lack of power to do what is good or to be holy. Being sensitive, he suffers from tortured human existence as well (Sonnets 1, III, IV, V). Moreover, he affirms the fact that the separation of the spirit from God results in an extreme moral deformity of an otherwise beautiful creature of God. Man is made "a little lower than angels" (Psalm, 8:4-5), but his sinfulness afflicts him, warping his being. And in that state, darkness pervades his languishing spirit: 
I am a little world made cunningly

Of Elements, and an angelic sprite,

But black sin hath betray'd to endless night

My worlds both parts, and (oh) both parts must die...

…

But oh it must be burnt! alas the fire

Of lust and envy have burnt it heretofore,

And made it fouler; ....

(V. 1-4, 10-12)

Spiritual death renders man morally impotent: "dead in trespasses and sins" (Eph. 2:1), thus, he is incapable of bearing good fruit because he is completely overpowered by human frailty. Donne's lines convey such thought which, following Eliot's comment, is an experience, that is, Donne's experience of spiritual death: a prime demonstration of how "black sin hath betray'd to endless night."

Second, Donne is also haunted by the inevitability of physical death as vividly dramatized in Sonnet V1:

This is my play's last scene, here heavens appoint

My pilgrimages last mile; and my race

Idly, yet quickly run, hath this last pace

My span's last inch, my minute’s latest point,

And gluttonous Death, will instantly unjoint

My body, and soul, and I shall sleep a space,

(V1. 1-6)

In the last clutches of physical death, man is helpless. When the "last mile" is reached, he has no choice but to give way. However, Donne's awareness of heaven as the destiny of a soul "purged of evil" as it leaves its physical body is a source of relief; by imputation, Christ's righteousness is received by a sinner.

Third, there is eternal death, the final destruction brought about by sin:

...my feeble flesh doth waste

By sin in it, which it towards hell doth weigh;

Also, the "black soul” is “damn'd and haled to execution” (1V. 1, 7), echoing the punishment incurred by sin because of God's wrath.

Relative to the idea of sin is Donne's allusion to the devil, the "old subtle foe" (1.11), the ally of the "world and the flesh". He is the persistent adversary, the "roaring lion, seeking whom he may devour" (1Pet. 5:8). His snares are inescapable and he controls the spirituality dead, destined to suffer God's wrath. Donne, who succumbs to his wiles, is never an exemption: "Satan (has) stolen" him (XV.12), and he exclaims, "And Satan Hates me, yet is loth to lose me" (II.14). The contradiction in this line demonstrates a powerful figure organically linked with spiritual battle.

True to the human condition, Donne's poems leave traces of painful grimaces due to sin. The depths of man's captivity and wantonness are never ignored, but are amplified by the emotional impact of the vicarious yoke impressed by his literary form: the peculiarly reflective mood, the nervous provocations, the earnest pleadings. 
It is Donne's keen moral orientation that makes his appraisal of man's spiritual state accurate, realistic, and credible. He is not a romantic who dreamily paints man as an angelic being, untainted by the effects of sin, nor a humanist who elevates man, puts him on a pedestal, and ignores his wickedness; but he is a realist who calls a spade a spade, and a Christian who sees man's totality in the light of the Scriptures. Significantly enough, it is Donne's genuine sense of human depravity that allows for the other theme of Christianity to be introduced, viz., grace and salvation. Truly, "the wages of sin is death, but the free gift of God is eternal life through Jesus Christ.” (Rom. 6:23).

When Donne reflects on the degradation which is innate in man, he is able to focus more sharply the luminosity of God's love: the darkness in man's soul makes the grace of God glow even brighter. Donne admits humbly his dire need for supernatural power that is able to rescue him from the bondage of Satan. With the guidance and help of the Spirit of God, his knowledge of God's Word assures him that if he repents and trusts in the work of Christ on the cross, he shall be forgiven. Echoing Isaiah 1:18 "though your sins are scarlet, they shall be as white as snow; though they are red as crimson, they shall be like wool,” Donne dramatically portrays the idea of cleansing through kaleidoscopic imaging and paradoxical dyeing of red soul to white:

Yet grace, if thou repent, thou canst not lack;

But who shall give thee that grace to begin?

Oh make thyself with holy mourning black,

And red with blushing, as thou art with sin;

Or wash thee in Christ's blood, which hath this might

That being red, it dyes red souls to white.

(IV. 9-14)

The implications of God's bestowing grace upon man are also well-articulated. Besides forgiveness, explicit in the following lines:

Teach me how to repent; for that's as good

As if Thou hadst seal'd my pardon, with thy blood.

(VII. 13-14)

and Christ redemption of man from Satan’s clutches,

His stolen stuff sold, must lose or buy it again:

The Son of glory came down, and was slain,

Us whom he had made, and Satan stole, to unbind.

(XV. 10-12)

There is also man's victory over death. First, Christ's atonement for sin, the purchase of his blood, brings to life anyone who puts his faith in Him: the power of the sinful self may now be destroyed so that man is no longer a slave of sin. Or, the spirituality dead may now be made alive in Christ. Donne's line, "This Lamb, whose death, with life the world hath blest" (XVI. 5) is reminiscent of the biblical verse "He that hath the Son hath life, he that hath not the Son of God hath not life." (1 John, 5:12) Second, there is victory over physical death because even this leads to eternal life. Thus, Donne has the celebrated Sonnet X, "Death be not proud...," in which he puts forward the idea that "One short sleep past, we wake eternally." Again, this has Biblical overtones: that he who is in Christ, though he dies yet shall he live. (John, 11:25) Or, in Paul's ecstatic utterance, "O death where is thy sting? O grave where is thy victory?” (1 Cor. 15:25) Correlative to the 
powerlessness of physical death and its total subjugation is the doctrine of the resurrection of the body. Donne treats this as well:
At the round earths imagined corners, blow
Your trumpets, angels, and arise, arise
From death, you numberless infinities
Of souls, and to your scattered bodies go,
All whom the flood did, and fire shall o'erthrow,
All whom war, dea[r]th, age, agues, tyrannies,
Despair, law chance, hath slain, and you whose eyes,
Shall behold God, and never taste deaths woe.

(VII. 1-8)

Noteworthy is the last line which affirms the victory of grace over the third kind of death, i.e., eternal damnation and destruction. Because of Christ's death on the cross, "death's woe" will not be experienced: "There is therefore no condemnation to them which are in Christ Jesus.... For the law of the Spirit of life in Christ Jesus hath made (man) free from the law of sin and death” (Rom. 8:1-2).

The synthesis of the poet and theologian in Donne reaches its rapturous fulfillment in the Holy Sonnets. His corpus of poems embodying his Christology, in particular, can be counted not as a well-reasoned apologetic but a moving hymn of praise. In Christ dwells the fullness of everything - the answer to his spiritual yearnings. Since Christ is also God's revelation of himself, in Him Donne perceives an infinite love (Sonnet XI) expressed in "beauteous form" (Sonnet XIII). Von Balthazar's theological aesthetics is worth mentioning at this point. He believes that in gratuitous love, expressed in Jesus, lays the deepest root of beauty: "The Father is content, the son form-in the unique way shown by revelation". The substitutionary death of Christ is interpreted as the final expression of God's glory in the world. It is perhaps along this line that Donne's spiritual consciousness is primarily directed. Significantly, the quality of his faith draws its inspiration from the unfathomable love of God.

Donne's poetic response to such infinite love exudes an intense passion which is easily understood if his emotional timbre is considered. He is by nature highly strung. Thus, his sense of personal guilt and unworthiness is marked by the strain and blast reverberating within most of his poems.

For instance, in Sonnet XI he bursts out,

Spit in my face you Jews, and pierce my side,

Buffet, and scoff, scourge, and crucify me,

For I have sin'd, and sin'd, and only he

Who could do no iniquity, hath dyed:

But my death cannot be satisfied

My sins, which pass the Jews impiety:

They kill'd once an inglorious man, but I

Crucify him daily, being now glorified.

(XI. 1-8)

Or in Sonnet XII, he wonders,

Why are wee by all creatures waited on?

Why doe the prodigall elements supply

Life and food to me, being more pure than I,

Simple, and further from corruption? 
Why brook'st thou, ignorant horse, subjection? '

Why dost thou bull, and bore so seelily

Dissemble weakness, and by 'one' mans stroke die,

Whose whole kind, you might shallow and feed upon?

Weaker I am, woe is me, and worse than you,

You have not sin'd, nor need to be timorous.

(XII. 1-10)

By and large, the paradox of grace - the perfect union of God and man in Christ—is not simply a dogma, but a gripping reality to Donne, breathing in him new life. And, interestingly enough, it is not only his spirit that is animated, but even his poetic muse is awakened, so to speak. Being totally involved, almost consumed by the Divine, he cannot restrain the vociferous externalization of his feelings. For instance, in his celebrated Sonnet XIV, he uses paradox and violent language to render his intense desire to be possessed by God. Verbally potent:

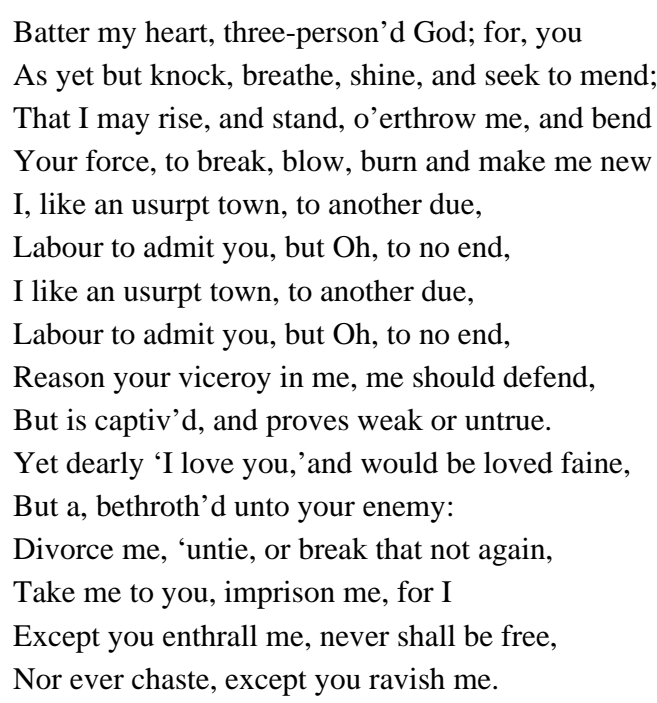

Like a crescendo in the poetic orchestration of Donne's Holy Sonnet's, such intense beating of excessive passion for God calls for a deeper devotion. Nothing can be more baffling than the compulsive "Batter my heart, three-person'd God" to address the Divine, yet this mold of poetic discourse communicates Donne's resolute thrust. His authentic intercourse with the mighty and powerful God underlies his use of potent words. Anything less will dissipate the burning energy of his formidable religious experience.

In keeping with his non-traditional tone in his religious poems, he uses wrenching paradoxes ("Except you enthrall me, never shall be free, nor ever chaste, except you ravish me”) rather than didactic stirrings to express what a soul-starved, wholehearted relationship with God is. A wordsmith, Donne shapes his poem rigorously and steadfastly. Given his rational yet penetrating imagery, the thoughts directed to the object of his contemplation generate transcendent spiritual vision and understanding of his intimacy with God.

That the Christian faith is "always a scandal to the imagination and reason of the flesh" may be taken literally in Donne's case. Besides the incomprehensibility of the incarnation and atonement on the cross, the doctrines to which Donne fully subscribes and the reality of which he experiences in the sonnets, there is his distracting, unnatural and shrill way of expressing his meditations. And his "poetic language expresses an experience which is not accessible to us in normal life” (Lewis, p. 133), but such experience he makes available 
to anyone who wants to deliver the same thoughts and feelings to God. And the Divine who is "previous" has a compelling reason to be tangible and is ready to interact, sometimes even in an ironic twist (such as in responding to Donne's shocking display of familiarity).

Perhaps it is the masculine and vigorous quality of Donne's Holy Sonnets that allows his faith to reflect its source: a God who is alive and personal, touching even a most peculiar temperament. Not a set of lifeless and mechanical dogmas, nor habitual liturgical acts, but an encounter with a holy and majestic God is Donne's faith. His sonnets are indeed an occasion of wonder. Donne has articulated his thoughts with staggering familiarity, and then the Divine is grounded right in the heart of his holy sonnets.

\section{References}

Donne, J. (1896). Poems of John Donne. (vol I.). (E. K. Chambers, Ed.). London: Lawrence \& Bullen. Retrieved from http://www.luminarium.org/sevenlit/donne/holysonnet1.php

Dostoyevsky, F. (1983). The Brothers Karamazov. (D. Magarshack, Trans.). Great Britain: Hazell Watson \& Viney, Ltd.

Dyrness, W. (1971). Roault: A vision of suffering and salvation. Grand Rapids, Michigan: William B. Eerdmans Publishing Co.

Eliot, T. S. (1980). The metaphysical poets, selected prose of T. S. Eliot. (F. Kermode, Ed.). London: Faber and Faber.

Johnson, S. (1905). Waller. In George Birkbeck Hill (Ed.), Lives of the English poets (3 vols) (p. 291). New York: Octagon Books.

Lewis, C. S. (1968). Christian reflections. (W. Hooper, Ed.). Grand Rapids, Michigan: William B. Eerdmans Publishing Co.

Packer, J. I. (1997). Great grace. Eastbourne, UK: Kingsway Publications.

Rookmaaker. (1970). Modern art and the death of a culture. Chicago/London: Inter-Varsity Press.

Ruland, V. (1975). Horizons of criticism: An assessment of religious-literary options. Chicago: American Library Association.

The Holy Bible (New International Version). (1984). Grand Rapids, Michigan: Zondervan Bible Publishers.

Tozer, A. W. (1976). The pursuit of God. Harrisburg, P.A: Christian Publications, Inc.

Yancey, P. (1999). The Bible Jesus Read._Manila: OMF Literature. 